\title{
A critical reflection on the indigenous church leadership that behaves like modern-day pharoahs The lutheran church as a case study as we search for servant leadership that is liberating and transformative Olehile. A. Buffel ${ }^{1}$
}

\begin{abstract}
The article argues that when the indigenous leadership of churches in Africa took over it was a welcome relief, a process that must never be reversed. That take-over followed the cry for a moratorium and for indigenous leadership that was not given space by white missionaries who were at the forefront of the colonisation process. In this article, a question is raised as to whether indigenous leadership is offering leadership that is qualitatively different from that of white missionaries who were also regarded as modern-day Pharaohs and who were incapable of liberating and transforming the church and society. Sadly, indigenous leadership is emulating the behaviours and tendencies of those who were seen as modern-day Pharaohs and subsequently the church is not able to be true to its nature and mission work. The article looks at the ancient Pharaohs and their tendencies and concludes that there are some similarities between the leadership of missionaries and indigenous leadership. The article makes a case for different leadership that is selfless, ethical and service-oriented as taught and embodied by Jesus Christ.
\end{abstract}

Keywords: modern-day Pharaohs, indigenous, servant leadership, moratorium, Lutheran Church, ethical, liberating

\section{Introduction}

In the past, Africans in various churches cried out for indigenous leadership in the place of missionary leadership. The cry for indigenous leadership had arisen as a result of lived experience of domination and oppression under the leadership of white missionaries. Africans had felt that they were not able to fulfil their God-given potential and were hardly given space to grow, to lead or to share meaningfully in leadership. They were not trusted with leadership and were excluded from participation at different levels of the leadership of the African churches. The leadership of missionaries was regarded as very paternalistic, oppressive and incapable of bringing about liberation and transformation. The cry rallied around the dictum

Professor Buffel is in the Department of Philosophy, Practical Theology and Systematic Theology at the University of South Africa. He can be contacted at Buffeoa@unisa.ac.za. 
stating, "missionary go home!" The cry was associated with the call for a moratorium. Notwithstanding some of the benefits of colonisation, missionaries were what Steve Biko referred to as "being in the forefront of the colonisation process." The metaphor that was used in everyday conversations was that of missionaries referred to as "modern-day Pharaohs" who were incapable of liberating and transforming. Is the indigenous leadership offering leadership that is qualitatively different from that of missionaries who were regarded as "modern day Pharaohs?" In this article it is argued that indigenous leadership that was called for has not yet been able to transform African churches. The leadership continue to subject their members to Pharaoh-like tendencies that are negatively impacting churches and their growth. Furthermore, it is argued that for the church to be true to its nature and its mission, it must have leadership that is ethical, service-oriented, liberating and transformative. The Lutheran church is used only as a case study, as this is the case for many other churches.

\section{The problematic entanglement between missionaries and colonial agents}

When missionaries came to what is now referred to as the developing world (socalled Third World), particularly Africa, they arrived in close association with the colonial powers and their agents. There was a close relationship between the "throne and altar," as part of the project of Western colonial expansion (Bosch, 1991:364). There was a very close entanglement between missionaries and colonial powers and agents. It was a continuation of what started with the Constantinian era. From that era the church had become a state church, with very cordial relations between the church and the state (Saayman, 1991:2). According to Bevans and Schroeder (2004:214), European countries such as Germany, Belgium, England, France and others aggressively expanded their colonial domains in the 1870s, initiating a period of high imperialism. During that period, representatives of some of the European colonial powers came together to divide the continent of Africa amongst themselves (Bevans \& Schoeder, 2004:214). During that period, churches and mission organisations displayed some dramatic growth (2004:214).

One cannot deny that initially missionaries came as ambassadors or representatives of the Western counties, as they attempted to "go to the ends of the earth for the sake of the Christian gospel" (Bosch, 1991:364). The colonial state expected that missionaries would aid them in "civilising" the "natives" (Saayman, 1991:2). In some cases, missionaries petitioned their governments to annex a territory before a rival could do so (Bevans \& Schroeder, 2004:214). Missionaries, with the support of their mission societies erected grand institutions such as schools, colleges, hospitals, church buildings, printing houses etc. There is no doubt that missions 
and missionaries brought some benefits to the mission fields and to countries in which they were operating. There were some benefits from some of the work done by missionaries, who were what Steve Biko referred to as "being in the forefront of the colonisation process." (Biko, 1978).

Many of the mission churches continued for centuries to do the following:

1. Provide human resources and leadership for churches in the mission fields. Local members were not trusted with provision of leadership for mission-established churches.

2. Provide financial resources and other material resources that built church buildings, schools, colleges, hospitals, printing houses. Financial support also contributed to salaries of personnel, both expatriates and local personnel.

3. Provide other forms of support to mission-established churches.

As the above were happening, there were often no conscious, deliberate, strategic efforts and plans to gradually equip and facilitate the take-over of indigenous leadership and to lead to self-reliance. The continued provision of the above served to postpone the coming of age of churches and that of African church leaders. That also served to postpone the development towards autonomy and self-reliance. As Grant (2005:70) correctly points out, "the colonial practice of keeping power in mission hands inhibits the development of indigenous leaders."

\section{The call for a moratorium as a call for home-grown indigenous leadership}

At one phase of the history of the developing counties, there was a call for liberation and the end of Western cultural and political dominance. This marked what Bevans and Shroeder referred to as "the transition from Western mission agency dominance to two-thirds world leadership" (Bevans \& Schoeder, 2004:263). As one African country after the other attained independence, the struggle for independence reached the churches. Subsequently there was a call for a moratorium on mission, that is, on financial resources and personnel, in view of allowing mission churches to grow on their own and attain autonomy and self-reliance. In 1971, a call for moratorium on missionaries was pioneered by Rev. Dr. John Gatu, an African church leader from Kenya (Bevens \& Shroeder, 2004:262). The call for a moratorium was supported by other respected leaders of the church from Africa and other parts of the world (Anderson, 1974:133; Makofane, 2009:11). As a result of the sustained call, John Gatu ${ }^{2}$ was later called "a missionary hater" by the West. It was not only a call for moratorium on missionaries, but on foreign aid to African churches to promote growth and self-reliance. Cited by Anderson, John Gatu said:

2 John Gatu was the General Secretary of the Presbyterian Church in East Africa. 
Our present problems can only be solved if all missionaries can be withdrawn in order to allow a period of not less than five years for each side to rethink and formulate what is going to be their future relationship... The churches of the Third World must be allowed to find their own identity, and the continuation of the present missionary movement is a hindrance to this selfhood of the church (Anderson, 2004:134).

Notwithstanding the fact that in many cases the call for a moratorium was not immediately heeded, the call and the debates that followed placed on the national and ecumenical agendas issues related to the independence of indigenous churches, training and taking over of indigenous churches, efforts to attain financial independence and self-reliance.

Much later than 1971, when the call for moratorium was made, in 1999, a bishop of the Methodist Church of Kenya, Bishop Zablon Nthamburiri said, "The African Church will not grow into maturity if it continues to be fed by Western partners. It will ever remain an infant who has not learned to walk on her own" (Pocock et al., 2005:280).

Although Anderson did not agree with the call for moratorium, he argued that the growing sentiment associated with the call for a moratorium was a sign of the church's vitality and an indication that the "younger churches" have come of age. He went on to argue that the leaders of those churches were ready and able to articulate "'this new sense of strength and confidence implies regarding the traditional structures of the relationship to the churches of the West" (Anderson, 1974:135).

The call for a moratorium was a call for home-grown, indigenous leadership. The leadership of the missionaries was experienced as paternalistic, patronising and oppressive. There may have been a few agents of colonialism and mission societies who displayed respectful attitudes towards Africans, while as a general trend and tendency they were disrespectful and had attitudes that regarded Africans as inferior, incapable, untrustworthy and in some cases less human than Europeans (Bevans \& Schoeder, 2004:216). Therefore, in general, no room was left for indigenous leadership, which was not trusted. It was as if in the minds of many (not all) European missionaries, all Africans, particularly their leaders were like children (perpetual children) who could not be trusted with leadership. African leaders were not any different from children, who could not be regarded as "agents of mission" (Botha, 2015:1). ${ }^{3}$ The missionary leadership during that missionary period was regarded as leadership that was incapa-

3 Prof Nico Botha was writing in the context of children as a theological hermeneutic and without any agency in mission and theology. Similarly, African pastors and Christians (adults included) were regarded as having no agency, hence the paternalistic attitudes towards them. 
ble of bringing about liberation and transformation. That lived experience led to the cry for indigenous leadership and the cry for a moratorium.

Even though there were forms of resistance to the call for moratorium, the debate raged on for many years. The debate placed on the agenda of the world and churches a critique of the kind of leadership that was provided by the missionaries and other personnel of mission societies. Various metaphors have been used with regards to the leadership, challenges and situations of the churches. Some say the church was and is still in or has gone back to Babylonian captivity. Others say the church is like very dry bones that need to be brought back to life through prophetic ministry. The metaphor that is used in this article is that of likening the oppressive leadership with ancient Pharaohs and suggesting that such leaders are not different from the ancient Pharaohs and therefore are referred to as 'modern day Pharaohs.' The ancient history of the Israelites, which may be regarded by many as irrelevant to the modern world, has examples of leadership that have parallels with our contemporary world. Even though the Exodus story is about God and Moses, we can learn a lot from the character, attitudes and behaviours of the ancient Pharaohs, with striking similarities with modern-day Pharaohs who are leading modern institutions and organisations, and particularly the churches at different levels of leadership. While the Lutheran Church (Evangelical Lutheran Church in Southern Africa [ELCSA]) is used as an example, the tendencies that are like those of ancient Pharaohs are common in many other churches.

\section{Ancient Pharaohs vis-à-vis modern-day Pharaohs}

There were numerous kings who are not identified by their names. They used 'the Pharaoh' as a royal title. The Pharaoh was thus the most powerful force known in the world during that time when the children of Israel migrated and settled in Egypt. For the purposes of our paper, we distinguish between at least three Pharaohs who are not identified by name in the actual biblical Exodus story, namely;

1. The Pharaoh who welcomed Joseph and later his brothers and their households.

2. The Pharaoh of the time of the birth of Moses.

3. The Pharaoh of the return of Moses.

The Hebrews were forced by famine to migrate and settle in Egypt. Although the Pharaoh of the time of Joseph was initially kind to the Israelites, the other Pharaohs were not so kind and hospitable. The unnamed Pharaoh of the time of Joseph promoted Joseph to a position of vizier ${ }^{4}$ of Egypt and gave him permission to bring his father and brothers and their families to Egypt to live in the land of Goshen. ${ }^{5}$

\footnotetext{
4 A Vizier was a high-ranking official in ancient Egypt who served the Pharaoh during the Old, Middle and New Kingdoms, including the Kingdoms of the Pharaohs.

5 The Eastern Nile Delta around modern Faqus. The land that was given to the Hebrews by the Pharaoh
} 
The kind Pharaoh even extended the kind of hospitality that allowed the children of Israel to settle in Egypt when they experienced famine. The children of Israel were herdsmen who owned their own animals and ran their own affairs. They had taken advantage of their welcome and the conditions of North Egypt and had borne children "so that the land was filled with them" (Ashby, 1998:10). They increased in numbers to the extent that the Egyptians began to fear for their own security (Rogerson et al., 2001:183; Ashby, 1998:9, 10). Their success bred xenophobic attitudes, pretty much like in recent years were migrants in South Africa and their prosperity often end up in unpleasant repercussions.

According to the Exodus story, one of the sons (infant) of the Hebrews was saved and kept alive by king Pharaoh's daughter and was adopted into the royal household. That was a factor that contributed towards kindness and hospitality to the Hebrews.

While all Pharaohs were very oppressive, the degree of oppression and hardship differed over generations. It became more difficult and oppressive when the Hebrews increased in numbers and became more prosperous. During that period of growth and prosperity, there "arose a king over (a king came to power) Egypt who did not know Joseph" and "the children of Israel" (Exodus 1:8). This Pharaoh saw the growing and prosperous Hebrews as a threat to his sovereignty. All kinds of unfounded accusations were levelled against the Hebrews. The accusations concealed a real fear in the mind of the Pharaoh that the Hebrews might join with enemy invaders, in case of attack by foreign powers. It was a hypothetical threat according to which they were suspected of the possibility of joining forces with enemies in the case that Egypt is invaded from abroad or in case the Pharaoh's rule was subjected to protests from within (Exodus 1:9-10). The perceived threat led to fear, resentment, discrimination, oppression, persecution and eventually extermination (Ashby, 1998:12). The Pharaoh played on the prejudices and fears of his people to justify his own racist and xenophobic attitudes (Ashby, 1998:10; Exodus 1:8-10). Paranoia is as old as humanity and continues to this day amongst the leadership, especially those with Pharaohlike tendencies, both within and outside churches. People who are critical and who attempt to correct are often seen as enemies. Like ancient Pharaohs, modern-day Pharaohs are incapable of tolerating criticism, including constructive criticism.

The Pharaoh ordered enslavement under brutal and degrading conditions (Newsome, 1998:5). The Pharaoh said to his fellow Egyptians, "let us deal shrewdly with them" (verses 9-10). The Hebrews were subjected to the following:

1. Enslavement and oppression. The Hebrews were turned overnight into slave labourers (Exodus 1:11).

6 That they filled the whole land may be a bit of an exaggeration since they only occupied the Goshen Area (Exodus 9:26). 
2. Forced labour, which is tantamount to economic exploitation. They made their lives bitter with hard labour.

3. The threat of persecution and imprisonment.

4. The threat of being killed and the actual infanticide from which Moses was saved. All male infants were to be thrown into the river, as if sacrifices were being offered to the river "god" (Ashby, 1998:12). This is what during our time is referred to as genocide or ethnic cleansing.

When there was a change of regime, it was not a change for the better but for the worst. The new regime showed neither knowledge nor understanding of the rights and privileges of the Israelites (Ashby, 1998:9). The new regime displayed no kindness and mercy to the Hebrews. It is worth noting that the Hebrews had not committed any seditious act or subversive conspiracy (Newsome, 1998:5). Their only crime or sin was to increase in numbers and to prosper. Their sin was to be different. Being different provoked hatred of the other. Instead of weakening the Hebrews and decimating their numbers, the oppression and enslavement served only to further strengthen the Hebrews.

According to Newsome (1998:6), what the Pharaoh did rings true of the realities associated with human nature. Despots of the world often draw attention from their own weaknesses or even illegitimate leadership by conjuring up some imaginary external threat to national security. That is the same with despots from companies, organisations, academic institutions and even churches. In the case of the Lutheran Church, the despots have dealt ruthlessly with especially self-supporting pastors who are enemies of the church, notwithstanding their contributions to building up the church and serving the church.

The leadership of the Pharaoh who did not know Joseph and the Hebrews can be characterised as follows:

1. The Pharaoh felt threatened by the growth in numbers and the prosperity of the Hebrews.

2. The Pharaoh was a liar and was not a friend of the truth, as the Hebrews had not committed any seditious or subversive action.

3. The Pharaoh was paranoid and insecure.

4. The Pharaoh was abusive, oppressive and cruel.

5. The Pharaoh was determined to deal harshly and shrewdly with the Hebrews.

These characteristics bear striking similarities with the modern-day Pharaohs, that is, leadership of the churches, particularly the Lutheran church. This is the leadership that consists of those who are abusive, oppressive, cruel and often paranoid. They often deal with their flock harshly and shrewdly. That is the case especially when they are critiqued, corrected or questions are raised about aspects of their leadership that are unhelpful or destructive. In fairness to the ancient Pharaohs, they were products of their time and ruled long before the dawn of modern democ- 
racy, modern-civilisation, and the current culture of respect of human rights and justice. The contemporary world has no place for the Pharaoh-kind of behaviour, especially in the world that has become democratised and civilised over the centuries. Though sadly, there is an abundance of modern-day Pharaohs in churches who have the same characteristics and tendencies that the ancient Pharaohs had, as listed above. These are the leadership who do not appreciate the gifts of others. Instead they see the gifts of others as a threat. When others display some gifts that could be used for the growth of the church, they are suppressed, oppressed or in some cases eliminated.

\section{A cry for indigenous leadership}

The call for the moratorium related not only to the cry for autonomy and selfreliance, but it was also a cry for indigenous leadership. The hope then was that indigenous leadership would not have Pharaoh-like tendencies such as abuse, cruelty, oppression, exploitation, corruption or failure to listen to and understand Africans. Today, many churches have indigenous leadership. They also have serious problems of leadership. Many mainline churches have 100\% indigenous leadership, including ELCSA. This is an impressive progress from the situation that existed prior to 1975 when various regional churches merged to form one united Lutheran Church and ELCSA, which has seven dioceses. Following the Constituent Assembly of 1975 , it was hoped that the church would make progress with regards to the following:

1. Growth, both qualitatively and quantitatively (numbers and quality/spirituality). Over the years, throughout the Dioceses of ELCSA, the numbers have been declining. ELCSA is dealing with one crisis after the other and it is making headlines in the media for all the wrong reasons.

2. Strong leadership that can deal effectively regarding contemporary challenges.

3. Financial strength and viability. Michael Pocock correctly points out that "money is a two-edged sword, which can either empower or hinder missionary efforts" (Pocock et al., 2005:279).

4. Effective and meaningful programmes that help the church to respond effectively to the challenges of the time.

The church has failed dismally to attain the above. I attribute that to failure on the part of indigenous leadership. ELCSA is dealing with one crisis after the other and it is making headlines in the media for all the wrong reasons. There is serious leadership crisis in the church that seems to be in a 'permanent crisis.' One agrees with Connie Adams, that "it does not take a Solomon to know that many churches are suffering from a crisis in leadership" (Willis, 2010: v). The Lutheran Church, like many other churches, is no exception to this. 
Many of the problems, crises and conflicts in the ELCSA rotate around poor leadership. ELCSA is not an exception in having problems, conflicts, and crises due to a deficit of good, visionary and ethical, servant leadership. During the time when there was a cry of indigenous leadership in the church and ultimately exclusive black leadership took over the reins from missionaries of European descent, there were high hopes. In fact, in recent history some of those elected were literally lifted like superstars, or rather Messiahs who were going to lead the church to the "promised land flowing of milk and honey". The campaigns, lobbying and subsequent promises of some of those who were lifted at their consecration promised as much. However, the promises and dreams are dashed and deferred. Yes, having own black leadership must be embraced and celebrated. It becomes unfortunate that the black leadership that people so much desired and placed hopes on, have failed dismally. Not that people should cry for the cucumbers and pots of meat that they used to enjoy in Egypt (during white missionary leadership). The hope was that the indigenous leadership would be ethical, service-oriented, liberating and transformative. It will not necessarily help the flock or critics of leadership, to emulate the Hebrews of old who complained, and wept again and again:

"Oh that we had meat to eat! We remember the fish we ate in Egypt that cost nothing, the cucumbers, the melons, the leeks, the onions and garlic. But now our strength is dried up, and there is nothing at all but manna to look at" (Numbers 11:4-6).

They later grumbled again when there were some challenges:

"It would have been better to die in Egypt or even in the wilderness... Wouldn't it be better to go back to Egypt?" (Numbers 14:1-5).

The takeover of indigenous leadership is welcome. However, the leadership always must be held ethical and accountable. The leadership must embrace servant leadership and emulate Jesus Christ, who is the servant par excellence.

\section{Instances of questionable leadership in the Lutheran Church}

There are many instances of questionable unethical, selfish Pharaoh-like leadership that are common in many churches and in the Lutheran Church (ELCSA). One can only use a few concrete examples of the problematic leadership of the church. There are Pharaoh-like behaviours and tendencies among the leaders of the church that have led to one crisis after the other. These behaviours and tendencies have caused conflicts and considerable reputational damage to the church, as it makes headlines for wrong reasons. Since 2014, ELCSA has been making headlines for the 
wrong reasons. There were newspaper reports that reported the saga of the missing R40 million in the church, for which no one has ever been held accountable (2014-2019). To illustrate the reality of unethical behaviour information that is available in the public arena I will use such evidence as from Newspaper articles, website-based sources and letters that are readily available amongst members.

In an article by Neo Goba in the Sowetan Live it was reported on 1 August 2015 that the case of the missing millions has been escalated to the church's General Assembly (General Assembly of 24 July 2014, the highest decision-making body in ELCSA).

The General Assembly had a special meeting on 24 July 2015. The report goes on to state that an amount of R40 million was disinvested from Old Mutual with the understanding that it would be re-invested in an offshore investment (Neo Goba, 2015). The matter of the missing millions is also reported by the following:

- Ujuh reporter wrote on 2 July 2015 that, "R40 million is said to have disappeared from the coffers of the Evangelical Lutheran Church in Southern Africa in a development that seems to have introduced a feast of fury in the house of God. The matter is brewing into an embarrassing scandal for the Church".

- Sowetan July 2015, the front-page headline was "Missing R40 millions of rocks church."

- Zululand Observer of the 11 November 2016 had the following headline: "Mystery over Lutheran Church's missing R40 million". The headline followed a Diocesan Synod of the SED at which the matter of the missing millions was raised. (Umlazi).

- David Savides also reported the saga of the missing millions in the Zululand Observer in 2016.

- Thando Ndlovu also reported in the Zululand Observer of 27 July 2018.

The reports in the media follow an unfortunate event in December 2014 when R40 million was dis-invested from old Mutual and invested in a questionable scheme, without authorisation by appropriate structures such as Church Council and General Assembly. This happened a few weeks before the General Assembly of December 2014 by a few individuals who are part of the Executive Committee, which has no power over such matters.

The scheme had promised billions that would be used to build Luther City in Tshwane, with a Cathedral and some business units that would bring in more money for the Lutheran Church (Briefing on the R40 million saga by the Task Team 2015).

The transaction that led to the loss of R40 million was never authorised by the highest decision-making bodies of the Church, ELCSA Church Council and General Assembly. That became possible because there are individuals within the leadership of the church who have made themselves very powerful and often take decisions 
and actions that are beyond their powers (ultra vires). A decision of that magnitude should have been taken by the General Assembly, but it was done by these few individuals who have made themselves powerful and untouchable. These are the leaders who behave exactly like the ancient Pharaohs who are feared and account to no one, not even to the Councils of the Church. Only one bishop is on record as having objected to this transaction before it happened. He stated in an email that was appended to his report to the General Assembly.

In a report to the General Assembly of December 2016, ${ }^{7}$ the then presiding bishop of ELCSA, Bishop M. Ditlhale wrote:

I categorically state that there is neither a Church Council nor General Assembly decision to disinvest or go ahead with the financing of the Luther City Project... that decision was made by Exco through telecom ${ }^{8}$ and this was not presented to Church Council for ratification (Ditlhale, 2016:5).

Later in the same report, the then presiding bishop had this to say:

May I repeat, there was no approval by either General Assembly or Church Council ${ }^{9}$ to disinvest the funds from Old Mutual and pay that to Anani (Ditlhale, 2016:6).

In contrast, the Church Council had, upon learning of the possibility, given an explicit instruction that due diligence must first be done. At a special General Assembly meeting of July 2015, an outgoing presiding bishop (before Bishop Ditlhale) had apologised and admitted that due process was never followed. Though sadly the people responsible for the disappearance of the R 40 million have not faced any suspension or disciplinary action pending due process. This is an indication of the powers that a few individuals have, and they do as they please, even in cases where the highest decision-making bodies have taken decisions. The powerful are defended by a few others and the wrong decisions and actions enjoy impunity.

7 General Assembly is the highest decision-making body of the Church that meets once every two years in December, except for special meetings when the need arises.

8 A member of the church who is not even a member of Church Council or its Exco phoned members of Exco and from that telephone consultation compiled a resolution which was used to implement the decision to disinvest R40 million from Old Mutual and invest the money in a company called Anani, with the promise that ELCSA would later receive R4 billion in two years' time (Presiding Bishop's Report to the 22nd General Assembly held on 5-8 Dec 2016).

9 General Assembly and Church Council are the highest decision-making councils of the church, with the latter responsible for the affairs of the church when General assembly is not in session. The investment into Anani happened in December, less than two weeks before the General assembly of December 2014. 
In a report to the General Assembly (No 22 of December 2016), the then presiding bishop of ELCSA, Rt. Rev. Bishop M. Ditlhale correctly conceded that there is a crisis in the church and wrote as follows:

This matter has caused great consternation to many in our church, it caused sleepless nights for many in our church and exposed the lack of proper governance structures and policies, lack of disciplinary policies and the possibility of church capturing... It would be remiss not to state right from the beginning that the crisis we are faced with is not simply a financial crisis, but a crisis of our common witness as a Church, as well as a challenge of the message of the Gospel in our time, to our members as well as society at large (Report of the Presiding Bishop, 2016:9, 10)..$^{10}$

In my view, it is even deeper than a crisis of our common witness. It is also a crisis of leadership, a crisis of ethical, servant leadership. The fact that no one has been held accountable since December 2014 to date (2019) is enough proof that there are modern-day Pharaohs who are feared and who account to no one, not even to the highest councils of the Church. This is symptomatic of the massive power that some people have, that makes them untouchable. This questions not only the leadership and ethics of those who are responsible but many other people who are in the various councils and allow such anomalies and abuses of power to persist.

The unintended consequences of the disappearance of R40 million are as follows:

1. The church remains divided, conflict-crises-driven. These conflicts and crises are consuming a lot of energy and resources that should be directed at building, strengthening the church and making it faithful to its mission work. In the last few years the church has been spending a lot of time either at the CCMA over disputes related to unfair and un-procedural suspensions and dismissals of its pastors, many of whom had decisions in their favour. This is in addition to spending time in courts of law.

2. The Lutheran Theological Institute (LTI), where Lutheran pastors were trained was closed and lecturers and other staff members lost their jobs (Garaba, 2018:358-359). According to Dr Francis Garaba,${ }^{11}$ the disappearance of the funds is said to have condemned the church and its student ministers into financial misery (Garaba, 2018:358). Many families and dependants of em-

${ }^{10}$ Bishop M. Ditlhale was reiterating a statement he had previously made at a Church Council of September 2015.

${ }^{11}$ Dr Francis Garaba is a Senior Lecturer at the University of KwaZulu-Natal, Information Studies Programme. 
ployees of the church suffered as a result. Thus, theological education in ELCSA is in disarray. Garaba (2018:360) correctly states that the closure of LTI, as a result of the disappearance of $\mathrm{R} 40$ million, had many ramifications regarding theological education in KwaZulu-Natal. The implications are not only for KwaZulu-Natal but southern Africa and Africa in general, as the institution was a residence to students from all over Africa, who were pursuing undergraduate and post-graduate studies at the University of KwaZulu-Natal.

3. Those who raised concerns and questions about the disappearance of the R40 million, and particularly around the impunity enjoyed by culprits, faced consequences such as being silenced, some threatened and others facing suspensions, termination of employment and withdrawal of ordination rights, without following due process.

4. A farm near Edenburg, Bethany 610 in the Free State, is subject to a number of claims under Restitution Act of 1994 and other claims from interested parties such as the current occupants of part of the farm under Bethany Communal Property Association Committee. The Beddie family and Khoisan and Griqua groups, are in the process of being sold at an auction, ${ }^{12}$ without any consultation with the interested parties.

All the above happened because of the absence of ethical, servant leadership of the church. The above happened because the people with powers are behaving like modern-day Pharaohs who account to no one, including the constituencies and councils that elected and appointed them.

\section{The need of servant leadership}

There is an urgent need for the leadership of churches, the Lutheran church to move away from unethical, selfish, self-serving, tyrannical leadership that is no different from the leadership of ancient Pharaohs. The leadership must engage in selfre-examination and self-correction, in view of embracing servant leadership which was not only taught but also embodied in Jesus Christ, who is the perfect model of servant leadership. This is the kind of leadership which, if it was prevalent in ELCSA, many of the scandals, conflicts and crises that are tearing the church apart, would be not be prevalent. That applies to all other churches that used to be under missionaries but are now under indigenous leadership.

Servant Leadership is a modern management/leadership concept that was popularised by Robert Greenleaf (Wolfgang, 2010:22). Though, the practice of serv-

12 By the time the article is published, the farm, Bethany 610 may already be sold, notwithstanding protest from some of the claimants, occupants of the farm and other stakeholders, including the author who attempted to intervene on behalf of the community and facilitated a meeting with the Executive Committee of ELCSA Church Council in 2018. 
ant leadership was demonstrated by Jesus Christ. Jesus models leadership through service, for instance, the washing of the feet of the disciples, as a concrete demonstration of the selfless way they were to serve others (John 13:12-15; Wolfgang, 2010:22). Jesus also urged his followers to be servants first, contrasting service in his kingdom with worldly "leadership styles". He said:

You know that rulers of the Gentiles lord it over them, and their high officials exercise authority over them. Not so with you. Instead, whoever wants to become great among you must be a servant, and whoever wants to be first must be your slave - just as the Son of Man did not come to be served, but to serve, and to give his life as a ransom for many (Matthew 20:25-28; Mark 10:10:42-45; Wolfgang, 2010:22-23).

A leader exists to serve others rather than to be served and only when that is realised will a leader serve with integrity (Delouse \& Brewer, 2004:20).

Greenleaf describes the concept of "servant leader" as follows:

The servant leader is a servant first... It begins with the natural feeling that one wants to serve, to serve first. Then conscious choice brings one to aspire to lead. That person is sharply different from one who is a leader first, perhaps because of the need to assuage an unusual power drive or to acquire material possessions... The leader first and the servant first are two extreme types. Between them there are shadings and blends that are part of the infinite variety of human nature. The difference manifests itself in the care taken by the servant - first to make sure that other people's highest priority needs are being served. The best test, and difficult to administer is, Do they grow as persons? Do they, while being served, become healthier, wiser, freer, more autonomous, more likely themselves to become servants? And what is the effect on the least privileged in society? Will they benefit or at least not be further deprived (Wolfgang, 2010:23).

Wolfgang (2010:23) goes on to identify ten characteristics of servant leaders, namely; listening, empathy, healing, awareness, persuasion, conceptualisation, foresight, stewardship, commitment to the growth of others and building "community." Any leader with these characteristics would not be found to be making decisions and taking actions that are selfish and that are not in the interest of the organisation that he/she is leading. A leader with such characteristics would not make decisions and take actions that have the potential to damage the organisation. In the case of the Lutheran church, those leaders who are responsible for the disappearance of $\mathrm{R} 40$ million and its unintended consequences would not have done that if they had the 
characteristics that are stated above as outlined by Wolfgang. The other leaders who failed to hold the culprits accountable, despite calls from members of the church and some leaders who are not so powerful, also lack the characteristics outlined above. Most importantly, they lack servant leadership.

Servant leaders achieve results for their organisations by giving priority attention to the needs of their colleagues and those that they serve (Wolfgang, 2010:23). They are often seen as humble stewards of their organisation's resources (human, financial and physical) (Wolfgang, 2010:23). A servant leader is a "willing slave" as Paul states, "Though I am free and belong to no man (person), I make myself a servant to everyone, to win as many as possible "(Cedar, 1987:142-143). Richard Foster describes what it means to be a servant or a slave:

But when we choose to be a servant, we give up the right to be in charge. There is a great freedom in this. If we voluntarily choose to be taken advantage of, then we cannot be manipulated. When we choose to be a servant, we surrender the right to decide who and who we will serve. We become available and vulnerable... Consider the perspective of a slave. A slave sees all his (her) life from the viewpoint of slavery... Voluntary servitude is joy" (Cedar, 1987:144).

\section{Power and power abuse by modern-day Pharaohs as the end of servant leadership}

A common practice for many of the leaders who behave like modern-day Pharaohs is amassing as much power as possible and abusing that power. They also take decisions and actions that are not in the interests of the organisations that they lead. That is exactly what happens in many Churches, including the Lutheran Church, where there are leaders who amass power and abuse that power. That is the end of servant leadership. It is that same power that makes them behave like modern-day Pharaohs and make them devoid of any servant leadership. Those who have made themselves powerful abrogate to themselves powers to even take decisions outside legitimate, democratically elected structures. They do not account to anyone and are even able to act beyond their powers (ultra vires). That is certainly what happened in the case of the disappearance of R40 million where individuals took a decision and acted outside a duly elected Church Council and General Assembly. Even when there was prima facie evidence of wrongdoing they remained in the high offices of the Church and the matter remains unresolved since 2014 to 2019. This scandal of the disappearance of R40 million is a classic example of the abuse of power by those who behave like modern-day Pharaohs.

The greatest threat to a servant's heart and to servant leadership is the craving for power according to DelHousaye and Brewer (2004:21). They go on to say 
that power in the wrong hands can have devastating repercussions (DelHousaye \& Brewer, 2004:21). That craving or ambition for power, for the sake of power is the death of servant leadership, according to Henri Nouwen (cited in DelHousaye \& Brewer, 2004:21). He went on to say:

We keep on hearing from others, as well as saying to ourselves, that having power - provided it is used in the service of God and your fellow human beings - is a good thing. With this rationalisation, crusades took place, inquisitions were organised; indians were enslaved, positions of great influence were desired... Every time we see major crisis in the history of the church... we always see that the major cause of rapture is the power exercised by those who claim to be followers of the poor and powerless Jesus (Nouwen in DelHousaye \& Brewer, 2004:21; Nouwen, 2004:58-59).

The greatest tool of servant leadership is leading by example. Jesus himself led by example. DelHousaye and Brewer (2004:21) state that "the greatest force behind the authority of a servant leader is leading by example. The authority, therefore, does not reside in the leader, but in the Head of the Body, Jesus Christ, and in following his example" (DelHousaye \& Brewer, 2004:21). Like Christ, the servant leader's goal is to mature others so that they will do likewise (DelHousaye \& Brewer, 2004:22).

Wolf says that the love of God is the root of all servant leadership (DelHousaye \& Brewer, 2004:22). This type of love is the sacrificial force foundational to all genuine Christian leadership (DelHousaye \& Brewer 2004:22). Delhousaye and Brewer (2004:22) pose a serious question, "can a servant leader really survive in a world of so much selfishness, competition, and abuse of power?" Yes, God empowers such leadership, because it is leadership after God's own design (2004:22), in accordance with what Paul says in Ephesians 4:11-16:

"It is he who gave some to be apostles, some to be prophets, some to be evangelists, and some to be pastors and teachers, to prepare God's people for works of service, so that the body of Christ may be built up until we all reach the unity in the faith and the knowledge of the Son of God and become mature, attaining to the whole measure of the fullness of Christ. Then we will no longer be infants tossed back and forth by waves and blown here and there by every wind of teaching and by the cunning and craftiness of men in their deceitful scheming. Instead, speaking the truth in love, we will in all things grow up into him who is Head, that is, Christ. From him the whole body, joined and held together by every supporting ligament, grows and builds itself up in love, as each part does its work." 


\section{Conclusion}

The cry for African leadership in the place of missionary leadership has come to bite the churches that are now under indigenous leadership. The latter may seem to be vindicating missionaries who did not trust Africans, treated them like children and subsequently excluded them from participation in leadership at different levels of churches in Africa. However, there should be no regret at all about having indigenous leadership. There is no turning back. Africans cannot cry for "meat, the fish, cucumbers, melons, the leeks, the onions, and garlic and the graves of Egypt" like the Hebrews did (Numbers 11:4-6; Numbers 14:1-5).

Members and leaders of African churches, including ELCSA must take responsibility and start holding the leadership accountable. They must unite in uprooting all tendencies that make leaders comparable to ancient Pharaohs. They must also be united in uprooting behaviours and tendencies that in the case of ELCSA have led the church from one crisis to another and from one conflict to the next. The members must eliminate all behaviours and tendencies of cabals that have rendered themselves powerful and untouchable, even when there is obvious wrongdoing.

The church and its leadership must, as a matter of urgency before self-destruction, do the following, inter alia, as part of the process of self-correction:

Honestly engage in self-examination.

Facilitate a process in which the church and its leadership acknowledge the flaws and shortcomings of the prevalent styles of leadership that have plunged the church in crises and conflicts.

Facilitate a process in which ethical, selfless, servant-leadership is embraced as taught and embodied in Jesus Christ (John 13:12-15; Wolfgang 2010:22).

Facilitate a process in which the leadership embrace the characteristics identified above such as: listening, empathy, awareness, conceptualisation, foresight, stewardship, commitment to the growth of others and building "community".

Doing the above can go a long way in eliminating Pharaoh-like tendencies and behaviours that are negatively impacting the churches growth, like the Lutheran Church. Furthermore, it is argued that for the church to be true to its nature and its mission, the leadership must be ethical, liberating, transformative and servant-like as modelled by Jesus Christ.

\section{Bibliography}

Ashby, G. 1998. Exodus: Go out and meet God. Grand Rapids, Michigan: WM Eerdmans Publishing Company.

Anderson, G.H. 2004. A moratorium on missionaries? In G.H. Anderson and T.F. Stransky (eds). Mission trends no 1. New York: Paulist Press. 
Bevans, S., \& Schroeder, B. 2004. Constants in context: A theology of missions. Maryknoll, New York: Orbis Books.

Biko, S. 1978. I write what I like. Oxford: Heinemann.

Bosch, D. 1991. Transforming mission: Paradigm shifts in theology of mission. Maryknoll, NY: Orbis Books.

Botha, N. 2015. Children as a theological hermeneutic: Is there a new epistemological break emerging? HTS Teologiese Studies/Theological Studies, 72(1).

Cedar, P. 1987. Strength in servant leadership. Texas: Word Books Publisher.

DelHousaye, D. \& Brewer, B. 2004. Servant leadership: The seven distinctive characteristics of a servant leader. Scottsdale: SBC Press.

Ditlhale, M. 2016. Report of the presiding bishop to the General Assembly beld in December 2016.

Garaba, F. 2018. The demise of the Lutheran Theological Institute Library and Archives in retrospect: Reflections of a Manuscript Librarian in Pietermaritzburg, South Africa. Missionalia 46(3), 355-366.

Goba, N. 2015. Church probe into missing millions. Available from: https://www.sowetanlive.co.za/news/2015/08/01- Church -probe-into-missing-millions (Accessed 15 March 2018).

Grant, I.L. 2005. Christian leadership and globalizing Christianity: Missiological Approaches. JAM 7(1), 63-84.

Makofane, K. 2009. The moratorium debate in Christian mission and the Evangelical Lutheran Church in Southern Africa. Pretoria: Unisa (M.TH).

Ndlovu, T. 2018. Drama as police monitor Lutheran Church. Zululand Observer-Weekender. Available from: https://pressreader.com (Accessed 28 October 2018).

Newsome, J.D. 1998. Exodus. Louisville: Geneva Press.

Nouwen, H. 1990. In the Name of Jesus. New York: Crossroads.

Pocock, M., Van Rheenen, G., \& McConnell, D. 2005. The changing face of world missions: Engaging in contemporary issues and trends. Grand Rapids, Michigan: Baker Academic.

Rogerson, J.W., Moberly, R.W.L., \& Johnstone, W. 2001. Genesis and Exodus. Sheffield: Sheffield Academic Press.

Saayman, W. 1991. Christian mission in South Africa. Pretoria: Unisa Press.

Savides, D. 2016. Mystery over Lutheran Church's missing R40 million. Available from: https://zululandobserver.co.za/128156/mystery-over-missing-millions (Accessed 15 March 2018).

Saayman, W. 1991. Christian mission in South Africa: Political and ecumenical. Pretoria: Unisa Press.

Willis, M. 2010. A crisis in Leadership. Kentucky: Guardian Truth Foundation.

Wolfgang, S. 2010. Simon Peter: Everyman as Leader. In A crisis of Leadership. Kentucky: Guardian of Truth Foundation. 